\title{
Rancang Bangun Aplikasi Konversi Bahasa Isyarat Ke Abjad Dan Angka Berbasis Augmented Reality Dengan Teknik 3D Object Tracking
}

\author{
Ane Annisa ${ }^{1}$, Nurul Hiron ${ }^{2}$, Muhammad Adi Khairul Anshary ${ }^{3}$. \\ ${ }^{1,2,3}$ Teknik Informatika Fakultas Teknik Universitas Siliwangi \\ 12ane.annisa@ student.unsil.ac.id, ${ }^{2}$ hiron@unsil.ac.id, ${ }^{3}$ adikhairul@unsil.ac.id
}

\begin{abstract}
Abstrak-Orang tunarungu berkomunikasi dengan cara menggunakan bahasa isyarat. Sulitnya orang tunarungu berkomunikasi dengan orang normal menjadi salah satu permasalahan yang cukup serius, karena apabila orang normal tidak mengerti bahasa isyarat maka ketika berkomunikasi dengan orang tunarungu akan ada kesalahan komunikasi, sehingga keinginan orang tunarungu tidak akan tersampaikan dengan baik. Salah satu cara memecahkan masalah dalam hal ini yaitu orang normal berlajar bahasa isyarat, untuk membuat orang normal lebih tertarik belajar bahasa isyarat yaitu dengan cara memanfaatkan perkembangan teknologi salah satunya penerapan teknologi Augmented Reality yang pada saat ini sedang banyak di bicarakan dalam perkembangan teknologi multimedia. Berdasarkan permasalahan yang ada maka di buat sebuah aplikasi dengan menerapan teknologi Augmented Reality tersebut pada aplikasi yang dibuat yaitu aplikasi konversi bahasa isyarat abjad dan angka dengan menggunakan teknik 3D Object Tracking yaitu salah satu fitur terbaru dalam metode markerless, pada teknik ini marker tidak lagi menyerupai kertas melainkan objek 3 dimensi seperti asbak, mainan mobil - mobilan, dan lain sebagainya. Marker yang di gunakan dalam aplikasi konversi bahasa isyarat yaitu abjad dan angka dalam bentuk kayu dengan ukuran 10x8 cm, pada kayu tersebut di terapkan warna warna yang terang. Melakukan scanning marker dilakukan di tempat yang terang karena pada pembuatan marker 3D Object Tracking intensitas cahaya menjadi salah satu keberhasilan terdeteksinya marker.
\end{abstract}

Kata kunci-3D Object Tracking, Augmented Reality, Bahasa Isyarat, Tunarungu.

\section{PENDAHULUAN}

Komunikasi merupakan suatu proses penyampaian ide atau pesan dari pihak satu ke pihak lain yang umumnya dilakukan dengan cara lisan ataupun verbal, yang dapat dimengerti oleh kedua belah pihak [1]. Berbeda dengan kondisi normal pada umumnya, seseorang yang menderita tunarungu mengalami masalah serius dalam perkembangan berbahasa, hal ini disebabkan oleh ketidakmampuan mendengar yang dialaminya. Ketidakmampuan mendengar ini secara otomatis menghambat seluruh aspek perkembangan berbahasa.
Meskipun dalam keadaan yang tidak normal, seorang penderita tunarungu harus tetap dapat berkomunikasi. Komunikasi dilakukan antar sesama penderita tunarungu maupun antar penderita tunarungu dengan orang normal. Bentuk komunikasi yang digunakan ialah dengan menggunakan bahasa isyarat.

Untuk dapat melakukan komunikasi 2 arah yang baik, maka dibutuhkan pemahaman bahasa isyarat dari keduabelah pihak yang berkomunikasi.

Benda nyata dan maya di lingkungan nyata, berjalan secara interaktif dalam waktu nyata, dan terdapat integrasi antar benda dalam tiga dimensi, yaitu benda maya yang terintegrasi dalam dunia nyata. Penggabungan benda nyata dan maya dimungkinkan dengan teknologi tampilan yang sesuai, interaktivitas dimungkinkan melalui perangkat-perangkat input tertentu, dan integrasi yang baik memerlukan penjejakan yang efektif [2]. Penerapan Augmented Reality dapat diterapkan pada pengenalan bahasa isyarat.

Dengan kemajuan teknologi saat ini dapat dibangun aplikasi konversi abjad dan angka kedalam bahasa isyarat, yang bertujuan untuk membantu proses pemahaman orang normal terhadap bahasa isyarat dengan memanfaatkan teknologi Augmented Reality dan menggunakan teknik terbaru dari fitur markerless Augmented Reality yaitu teknik 3D Object Tracking yaitu teknik dengan menggunakan marker 3 dimensi atau objek nyata, seperti sebuah asbak, mainan bebek, mouse, dan lain sebagainya.

Adapun batasan masalah dalam pembahasan ini adalah pembuatan aplikasi konversi bahasa isyarat abjad dan angka dibangun berbasis android dengan menggunakan marker dari kayu abjad dan angka dengan ukuran 10x8cm dengan warna cerah pada kayu. Bahasa isyarat yang digunakan adalah bahasa isyarat Indonesia atau sering disebut (BISINDO) yaitu bahasa isyarat yang di ciptakan oleh orang penyandang tunarungu.

Bahasa isyarat adalah bahasa yang mengutamakan komunikasi manual, bahasa tubuh, dan gerak bibir, bukannya suara, untuk berkomunikasi [3]. Kaum tunarungu adalah kelompok utama yang menggunakan bahasa ini, biasanya dengan mengkombinasikan bentuk 
tangan, orientasi dan gerak tangan, lengan, dan tubuh serta ekspresi wajah untuk mengungkapkan pikiran mereka. Terdapat dua bahasa Isyarat di Indonesia yaitu SIBI (Sistem Isyarat Indonesia) dan BISINDO (Bahasa Isyarat Indonesia) [4]. Banyak penyandang tunarungu yang tidak suka menggunakan SIBI dengan alasan terlalu berbelit-belit dan rumit digunakan. Penyandang tunarungu lebih menggunakan BISINDO yang cenderung lebih cepat dan ringkas dan mudah untuk di pahami oleh tunarungu. Maka dari itu dalam pembuatan aplikasi ini menggunakan BISINDO.

BISINDO adalah sistem komunikasi yang praktis dan efektif untuk penyandang tunarungu Indonesia yang dikembangkan oleh tunarungu sendiri. BISINDO digunakan untuk berkomunikasi antar individu sebagaimana sama seperti halnya dengan bahasa Indonesia pada umumnya. Contoh alfabet BISINDO seperti pada gambar 1 dan bahasa isyarat angka menurut kamus BISINDO seperti pada gambar 2 .
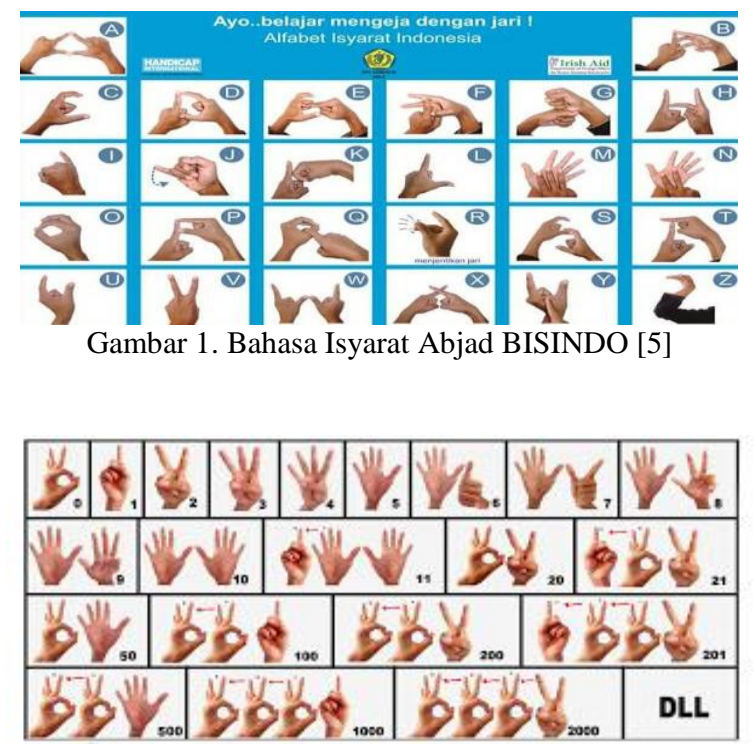

Gambar 2. Bahasa Isyarat Angka BISINDO [6]

Metode markerless (3D Objek Tracking) adalah salah satu fitur terbaru yang terdapat pada Marker tracking, markerless hampir menyerupai Marker Based Tracking (Single Marker) tetapi pada markerless pengguna tidak perlu lagi mencetak sebuah marker untuk menampilkan elemen-elemen digital [7]. Beberapa parameter yang menjadi factor keberhasilan dalam teknik ini yaitu, jarak untuk mendeteksi marker sekitar $30 \mathrm{~cm}$ atau bisa lebih, dan warna yang digunakan yaitu warna cerah atau RGB.

\section{METODOLOGI}

A. Metodologi Pembuatan Aplikasi

Dalam perancangan aplikasi konversi bahasa isyarat ini menggunakan metode pengembangan multimedia versi Luther-Sutopo [8]. Dengan 6 tahapan yang harus dilakukan secara berurutan, yaitu:

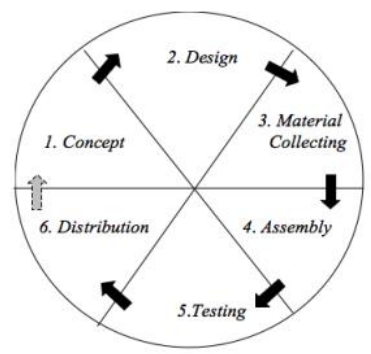

Gambar 3. Siklus Pembuatan Aplikasi Multimedia [8]

B. Metodologi Pengujian Marker

Dalam pengujian marker digunakan metode pengujian single marker yang di lakukan dengan beberapa percobaan yaitu menggunakan intensitas cahaya dengan ukuran sekala pengukuran yaitu lux,

Untuk pengujian marker dapat dilakukan dengan cara menggunakan handphone berspesifikasi tinggi minmal dengan RAM 2 GB dan kamera 8 MP. Pengujian di lakukan dengan menggunakan alat pengukur cahaya seperti lux meter. Beberapa contoh pelaksanaan pengujian marker seperti pada gambar 3-5.
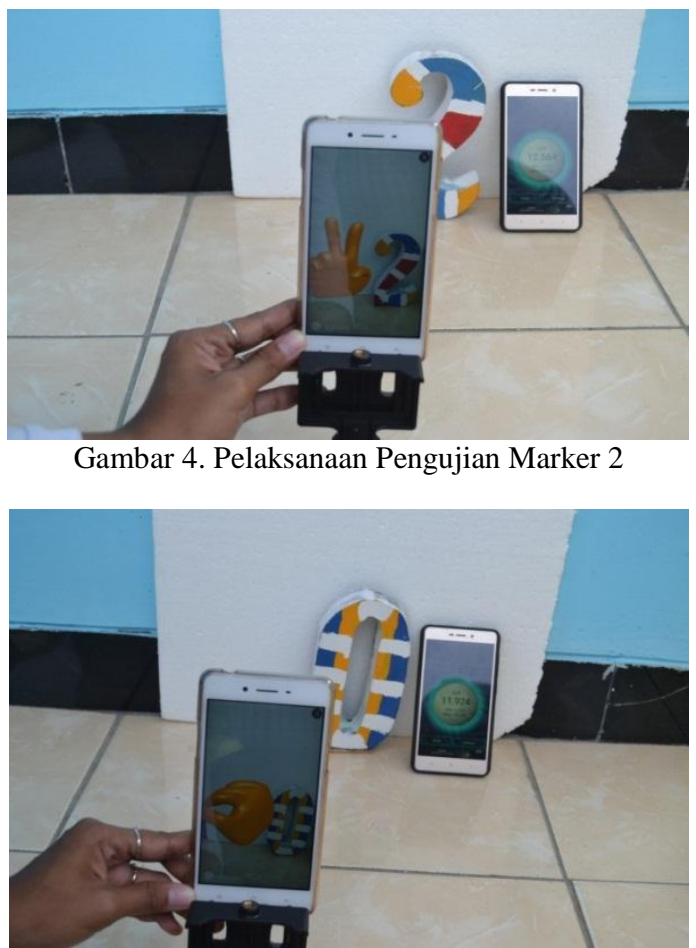

Gambar 5. Pelaksanaan Pengujian Marker O

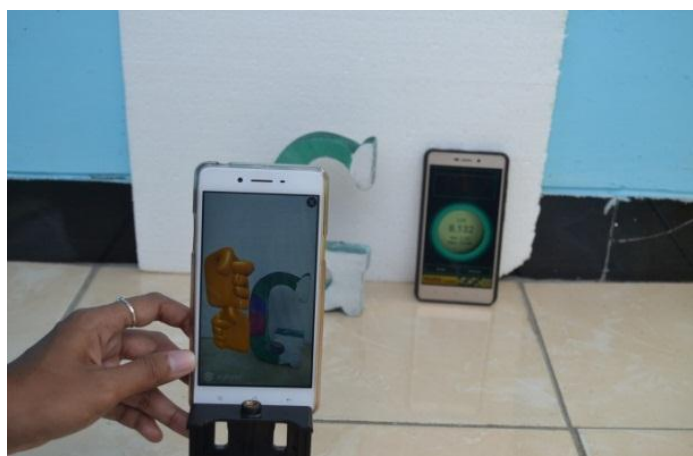

Gambar 6. Pelaksanaan Pengujian Marker G 


\section{HASIL DAN PEMBAHASAN}

A. Marker Objek Tiga Dimensi dan Gambar Bahasa Isyarat Tiga Dimensi

Marker objek tiga dimensi adalah sebuah objek yang dijadikan sebagai penanda yang berfungsi untuk mengidentifikasi gambar objek tiga dimensi yang akan ditampilkan pada layar handphone. Objek abjad dan angka yang digunakan akan di-scan dengan vuforia scanner data scan akan di unggah ke website resmi vuforia untuk mengubah file tersebut kedalam unity package sehingga objek terdeteksi dan dapat dijadikan marker untuk mengidentifikasi gambar bahasa isyarat.

Proses pembuatan model tiga dimensi (3D) pada aplikasi ini menggunakan Blender $3 d$ Modeling yang telah disesuaikan dengan kebutuhan pada aplikasi Augmented Reality konversi bahasa isyarat, yaitu objek gambar abjad dari A sampai $\mathrm{Z}$ dan angka dari 0 sampai 9.berikut adalah tampilan marker objek tiga dimensi dan gambar bahasa isyarat 3D pada tabel 1. dan tabel 2 .

Tabel 1. Marker Objek

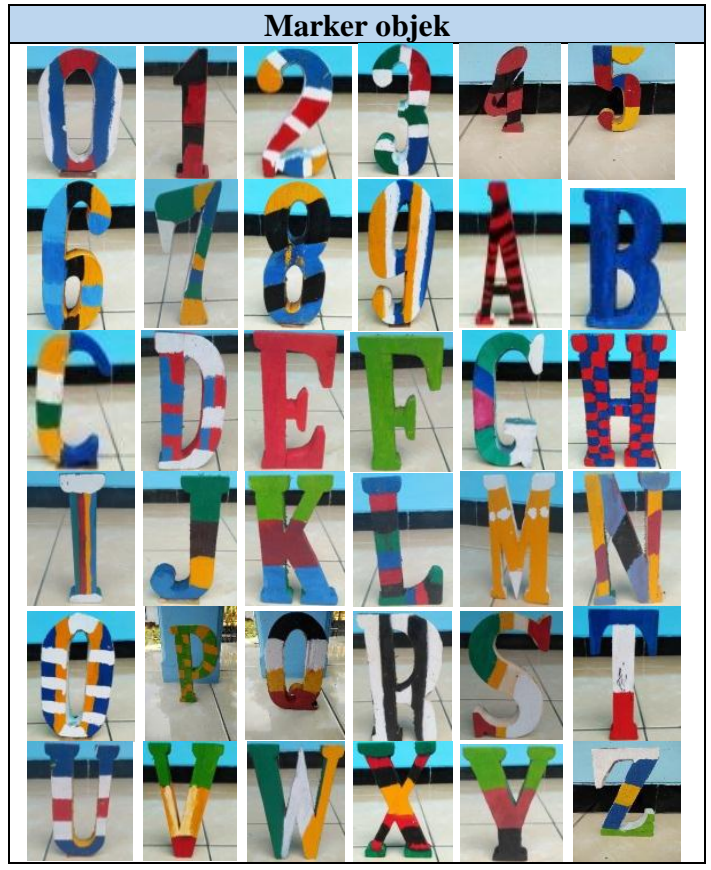

Tabel 2. Gambar 3D Bahasa Isyarat

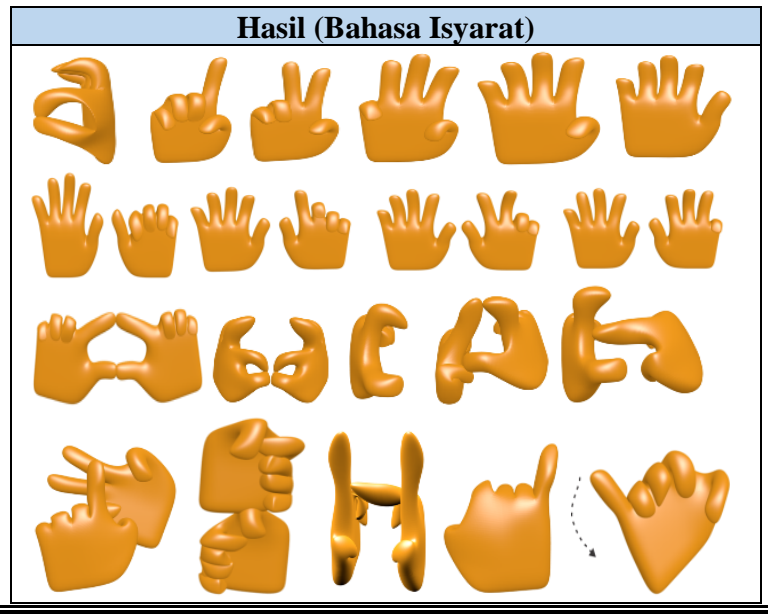

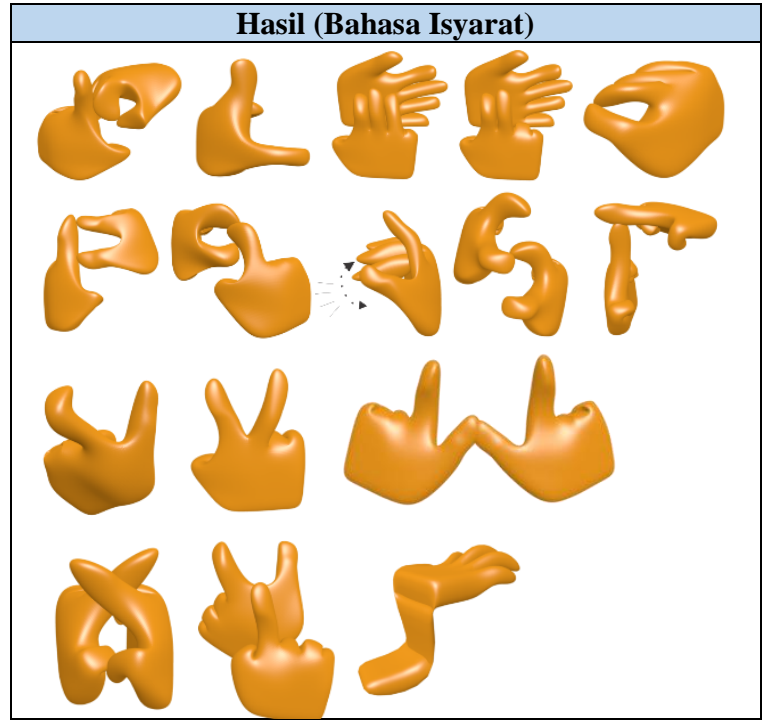

Setelah diketahui hasil pengujian pada scene menu dan tombol navigasi sesuai dengan skenario pengujian, maka langkah selanjutnya ialah melakukan pengujian terhadap marker. Pengujian dilakukan dengan menggunakan metode single marker, pengujian berdasarkan ukuran, tekstur, warna, jarak dari kamera, dan intensitas cahaya diukur dengan sekala pengukuran seperti pada tabel 3 dan untuk Pengukuran cahaya di lakukan dengan menggunakan Lux meter dari aplikasi di handphone android. Dengan skenario pengujian seperti pada tabel 3 .

Tabel 3. Parameter Pengujian Marker

\begin{tabular}{ccc}
\hline $\begin{array}{c}\text { Parameter } \\
\text { pengujian }\end{array}$ & Objek Pengujian & $\begin{array}{c}\text { Sekala } \\
\text { Pengujian }\end{array}$ \\
\hline $\begin{array}{c}\text { Bentuk dan } \\
\text { pola marker }\end{array}$ & $\begin{array}{c}\text { Marker 3 dimensi } \\
\text { dengan tekstur warna } \\
\text { dan ukuran }\end{array}$ & Points \\
Cahaya & $\begin{array}{c}\text {-cahaya lampu matahari } \\
\text {-cahaya lampu } \\
\text { penerangan }\end{array}$ & lux \\
& $\begin{array}{c}\text { Jarak kamera dari objek } \\
\text { kurang lebih } 28 \mathrm{~cm}\end{array}$ & $\mathrm{~cm}$ \\
\hline
\end{tabular}

Tabel 4. Skenario Pengujian dengan Intensitas Cahaya

\begin{tabular}{|c|c|c|}
\hline No & $\begin{array}{c}\text { Intensitas } \\
\text { Cahaya }\end{array}$ & Keterangan \\
\hline 1 & 7.873 Lux & $\begin{array}{l}\text { Pengujian dilakukan ketika siang hari } \\
\text { dan mendapatkan cahaya dari sinar } \\
\text { matahari dengan intensitas cahaya } \\
\text { 7,873 Lux dengan minimal 3.135Lux } \\
\text { dan maximal } 10.400 \text { Lux. }\end{array}$ \\
\hline 2 & 55 Lux & $\begin{array}{l}\text { Pengujian dilakukan di dalam } \\
\text { ruangan dengan intensitas cahaya } 55 \\
\text { Lux. Minimal cahaya di lingkungan } \\
48 \text { Lux dan Maximal cahaya } 71 \text { Lux. }\end{array}$ \\
\hline 3 & 6 Lux & $\begin{array}{l}\text { Pengujian dilakukan di dalam } \\
\text { ruangan yang gelap dengan } \\
\text { menggunakan lampu sorot intensitas } \\
\text { cahaya 6Lux dengan minimal cahaya } \\
\text { disekitarnya } 4 \text { Lux dan maximal } \\
\text { cahaya 7.124Lux. }\end{array}$ \\
\hline
\end{tabular}


Dengan intensitas cahaya yang berbeda dan warna marker yang gelap dan terang maka waktu deteksi marker juga berbeda, seperti pada tabel 5 dan gambar 6. yang menunjukan sebuah grafik dari tabel hasil pengujian marker. Pada grafik tersebut terdapat 3 intensitas cahaya, dengan waku respon yang berbeda.

Tabel 5. Hasil Pengujian Marker dengan Waktu Respon

\begin{tabular}{ccccc}
\hline & & \multicolumn{3}{c}{ Waktu Respon (detik) } \\
\cline { 3 - 5 } No & Objek & $\mathbf{7 . 8 7 3}$ Lux & $\mathbf{5 5 \text { Lux }}$ & $\mathbf{6}$ Lux \\
\hline 1 & 0 & 1 & 60 & gagal \\
2 & 1 & 3 & 180 & gagal \\
3 & 2 & 1 & 4 & gagal \\
4 & 3 & 1 & 4 & gagal \\
5 & 4 & 3 & gagal & gagal \\
6 & 5 & 3 & 60 & gagal \\
7 & 6 & 2 & 9 & gagal \\
8 & 7 & 2 & 8 & gagal \\
9 & 8 & 1 & 7 & gagal \\
10 & 9 & 3 & 60 & gagal \\
11 & a & 1 & 60 & gagal \\
12 & b & 2 & gagal & gagal \\
13 & c & 2 & 9 & gagal \\
14 & d & 2 & Gagal & gagal \\
15 & e & 2 & Gagal & gagal \\
16 & f & 2 & gagal & gagal
\end{tabular}

\begin{tabular}{ccccc}
\hline & & \multicolumn{3}{c}{ Waktu Respon (detik) } \\
\cline { 3 - 5 } No & Objek & $\mathbf{7 . 8 7 3}$ Lux & $\mathbf{5 5}$ Lux & $\mathbf{6}$ Lux \\
\hline 17 & $\mathrm{~g}$ & 1 & 8 & gagal \\
18 & $\mathrm{~h}$ & 2 & Gagal & gagal \\
19 & $\mathrm{i}$ & 4 & Gagal & gagal \\
20 & $\mathrm{j}$ & 6 & Gagal & gagal \\
21 & $\mathrm{k}$ & 6 & Gagal & gagal \\
22 & $\mathrm{l}$ & 2 & Gagal & gagal \\
23 & $\mathrm{~m}$ & 2 & Gagal & gagal \\
24 & $\mathrm{n}$ & 3 & gagal & gagal \\
25 & $\mathrm{o}$ & 1 & 4 & gagal \\
26 & $\mathrm{p}$ & 2 & Gagal & gagal \\
27 & $\mathrm{q}$ & 4 & 7 & gagal \\
28 & $\mathrm{r}$ & 1 & Gagal & gagal \\
29 & $\mathrm{~s}$ & 3 & 9 & gagal \\
30 & $\mathrm{t}$ & 4 & gagal & gagal \\
31 & $\mathrm{u}$ & 1 & Gagal & gagal \\
32 & $\mathrm{v}$ & 5 & Gagal & gagal \\
33 & w & 2 & Gagal & gagal \\
34 & $\mathrm{x}$ & 4 & Gagal & gagal \\
35 & $\mathrm{y}$ & 3 & Gagal & gagal \\
36 & $\mathrm{z}$ & 2 & gagal & gagal \\
\hline & & & &
\end{tabular}

Grafik Hasil Pengujian Waktu Respon

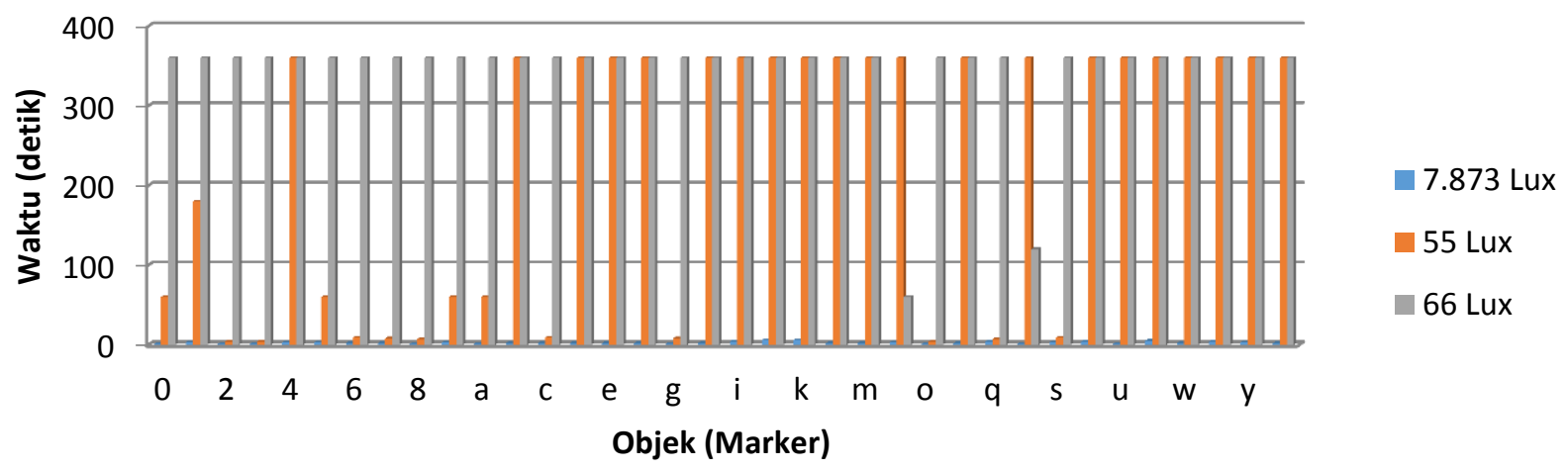

Gambar 7. Hasil Pengujian Waktu Respon Pada Intensitas Cahaya Yang Berbeda

Data hasil pengujian pada tabel 5 dan gambar 6 menggambarkan bahwa marker yang diuji pada intensitas cahaya 7873 lux berhasil di deteksi dengan rata-rata waktu respon 2,4 detik. Sementara marker pada intensitas cahaya 55 lux, tidak semua objek marker berhasil dideteksi. Dari jumlah keseluruhan marker sebanyak 36 objek, ada 15 objek yang berhasil dideteksi dengan rata-rata waktu respon 32,6 detik. Sedangkan pada intensitas cahaya 6 lux, semua objek marker tidak dapat dideteksi.

B. Pengujian Eksperimen
Pada penelitian ini dilakukan pengujian eksperimen atau pembuktian terhadap marker yang memiliki tekstur, warna, dan bentuk / ukuran yang tidak sesuai dan akan gagal tidak dapat terdeteksi.

a. Pengujian Marker Pada Tekstur

Pengujian dengan tekstur abstrak yang tidak jelas teksturnya pada marker maka marker tidak dapat di deteksi oleh vuforia ketika di scan untuk mendapatkan point sebelum dijadikan marker. Contoh marker tersebut terdapat pada gambar 7 . 


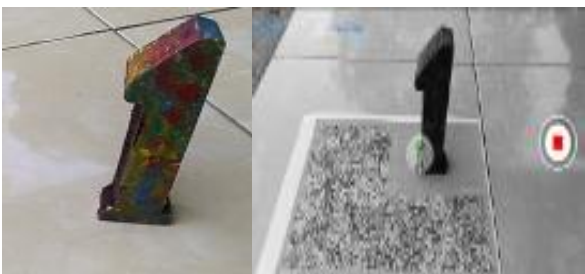

Gambar 8. Marker abstrak dan Scan Vuforia

b. Pengujian Marker Pada Warna

Pengujian dengan warna gelap bahkan tidak memiliki warna hanya ada warna asli dari kayu itu sendiri pada marker maka marker tidak dapat di deteksi oleh vuforia ketika di-scan untuk mendapatkan point sebelum dijadikan marker. Maka scan pada vuforia akan men-scan warna lain yang lebih cerah atau yang mempunyai tekstur. Contoh marker tersebut terdapat pada gambar 8 dan 9 .

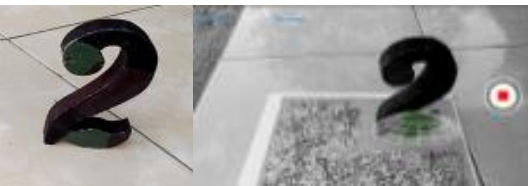

Gambar 9. Marker Warna Gelap

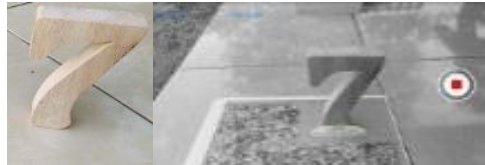

Gambar 10. Marker Tanpa Warna

\section{c. Pengujian Marker Pada Bentuk / Ukuran}

Pengujian dengan ukuran lebih kecil yaitu $4 \times 2 \mathrm{~cm}$ maka marker tidak dapat di deteksi oleh vuforia ketika di-scan untuk mendapatkan point sebelum dijadikan marker. ketika men-scan pada vuforia akan men-scan benda lain atau scan lebih lebar dari objeknya. Contoh marker tersebut terdapat pada gambar 10 .

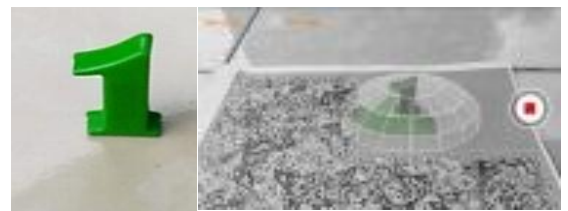

Gambar 11. Marker Ukuran Kecil

\section{KESIMPULAN DAN SARAN}

\section{A. Kesimpulan}

Berdasarkan hasil pembahasan dan implementasi dalam laporan Tugas Akhir ini, maka dapat di ambil kesimpulan sebagai berikut :

1. Aplikasi konversi bahasa isyarat dibangun berdasarkan penelitian yang telah dilakukan. Aplikasi dibuat dengan menerapkan teknologi Augmented Reality yang sedang ramai dibicarakan di bidang multimedia. Pembangunan aplikasi konversi bahasa isyarat pada abjad dan angka dapat berjalan dengan baik dan dapat digunakan untuk orang normal yang sedang memulai untuk belajar bahasa isyarat. sehingga orang normal dapat mempelajari bahasa isyarat dengan cara yang berbeda dan lebih menarik.

2. Pembuatan aplikasi Augmented Reality konvers bahasa isyarat abjad dan angka untuk membantu orang normal dibuat dengan teknik $3 \mathrm{~d}$ Object Tracking, dan user interface pada aplikasi di buat pada unity. Gambar 3 dimensi bahasa isyarat dibuat pada aplikasi blender $3 \mathrm{~d}$ modeling.

3. Teknik 3D Object Tracking dibuat dengan marker objek nyata yaitu abjad dan angka yang dibuat dari kayu dengan ukuran minimal $10 \times 8 \mathrm{~cm}$ dan di warnai dengan cat warna terang. Karena ketika objek abjad dan angka kayu tidak di beri warna ketika di scan pada vuforia scanner tidak terdeteksi. Karena vuforia scanner hanya dapat mendeteksi tekstur, warna dan bentuk / ukuran. Selain itu Intensitas cahaya dengan ukuran 10.000lux keatas akan menjadi faktor keberhasilan ketika melakukan scan di vuforia dan scan marker ketika aplikasi di jalankan.

B. Saran

Untuk pengembangan aplikasi Augmented Reality konversi bahasa isyarat, disarankan untuk melengkapi kekurangan, seperti :

1. Penambahan fitur aplikasi konversi bahsa isyarat seperti informasi pada objek animasi, tombol suara, tombol screenshot.

2. Melakukan pengembangan dengan teknik yang berbeda seperti hand tracking untuk pendeteksian tangan secara langsung.sehingga marker yang digunakan bukan lagi benda tapi tangan manusia.

3. Pengembangan aplikasi dengan menggunkan marker objek lain seperti hewan, buah - buahan dan lain sebagainya.

\section{REFERENSI}

[1] Endang, Y.P. (2013). Model scaffolding pembelajaran menulis dengan pendekatan proses bagi anak tunarungu. Tahun 41 nomor 2.

[2] Eka, M.A. dkk. (2016). Analisis Penggunaan Marke Tracking Pada Augmented Reality Huruf Hijaiyah. ISSN : 2085-3688, Vol. 8, No.1, Mei 2016.

[3] Luter, M. dkk. (2015).Aplikasi Alat Bantu Komunikasi Untuk Tuna Rungu Wicara.

[4] Nikol, F.A. (2014). Persepsi Siswa Tunarungu Terhadap Penggunaan Sistem Isyarat Bahasa Indonesia Dalam Komunikasi. Vilume 3. Nomor 3.

[5] Bisa mandiri (2015). Anak tuna rungu dan konsep Bahasa yang tepat bagian 2; https://bisamandiri.com/blog/2015/10/anaktuna-rungu-dan-pengenalan-konsep-bahasa-yang-tepat-bagian2/; diakses tanggal 9 April 2017.

[6] SLB Negeri Batu Raja (2012); Kamus Bahasa Isyarat Karya anak SLB Negeri Batu Raja. http://slb-negeribaturaja.blogspot.co.id/2012/06/kamus-bahasa-isyarat-karyaanak-slb.html. diakses tanggal 9 April 2017.

[7] Setyawan, R.A. (2016). Analisis Penggunaan Metode Marker Tracking Pada Augmented Reality Alat Musik Tradisional Jawa Tengah. Vol. 7, ISSN: 2252-4983.

[8] Binanto, Iwan. (2010). Multimedia Digital : Dasar Teori dan Pengembangannya. Yogyakarta: CV ANDI OFFSET. 